\title{
THE EFFECT OF FLIPPED CLASSROOMS ON L2 LEARNERS’ DEVELOPMENT AND RETENTION OF GRAMMATICAL KNOWLEDGE
}

\author{
Ahmad NOROOZI \\ ORCID: 0000-0003-3871-5936 \\ English Department, Isfahan (Khorasgan) Branch \\ Islamic Azad University \\ Isfahan, IRAN \\ Dr. Ehsan REZVANI \\ ORCID: 0000-0001-8996-0312 \\ English Department, Isfahan (Khorasgan) Branch \\ Islamic Azad University \\ Isfahan, IRAN \\ Dr. Ahmad AMERI-GOLESTAN \\ ORCID: 0000-0002-4502-3017 \\ English Department, Isfahan (Khorasgan) Branch \\ Islamic Azad University \\ Isfahan, IRAN
}

Received: 24/02/2019 Accepted: 04/04/2019

\begin{abstract}
The present study was conducted within the framework of sociocultural theory to examine the effect of flipped instruction on Iranian English as a foreign language (EFL) learners' development of conditional sentences. The study benefited from quantitative methodology within which 60 intermediate Iranian male EFL learners who were checked for their language proficiency by an Oxford Quick Placement Test (OQPT) to meet the homogeneity assumption were selected and given a pre- and post-test as well as a delayed post-test on conditional sentences. Half of the learners formed the experimental group and the remaining participants were assigned to the control group. The flipped instruction occurred through WhatsApp and was amplified by face to face discussions on the linguistic materials. Online learning environment armed the learners with the formal instruction of conditional sentences while the in-class time was devoted to tap into meaningful interaction for internalizing the previously-uploaded audio and video grammar tasks. The learners in the control group were provided with direct instruction by using traditional whiteboards. Results revealed that the experimental group, receiving flipped teaching, outperformed the control group that received conventional type of grammar instruction. Moreover, the use of flipped model resulted in significant improvement in learning and retention of conditional sentences. Findings also demonstrated that learners benefited from flipped-taught grammar augmented through feedback in the face-to-face classroom, which acts as the mediator between the teacher and the learners. It can be strongly recommended that teachers can take advantage of flipped instruction in providing effective instruction of language skills and sub-skills and facilitate the learning process for the learners as well.
\end{abstract}

Keywords: English Language Teaching, Flipped instruction, grammar learning, sociocultural theory

\section{INTRODUCTION}

Technology has been the focus of second and foreign language instruction since the 1960s (Blake, 2008; Warschauer \& Healey, 1998). Theories such as behaviorist perspective highlighted the application of technology in teaching by directing the scholars' attention toward using computer and mobile (Warschauer 
\& Healey, 1998). Then, behavioristic approach was rejected in the late 1970 s and early 1980s by sociocognitive view, arguing that teaching language skills takes place in an authentic environment by using a variety of technological tools, instead of visiting the computer lab once a week (Warschauer \& Healey, 1998; Kalin, 2012).

The idea of flipped classroom, initially known as inverted classroom, was introduced by Jonathan Bergmann and Aaron Sams in 2007 when they benefited from using video lessons to increase the quality of teaching chemistry. They recorded class lectures and the learners were provided with the online videos to watch and review the teaching contents. The study contributed to significant findings, which inspired the two teachers to further employ it before classes. They argued that flipped teaching provides a warm-up before class when learners come to class knowing exactly what they are expected to do. This pre-existing knowledge enables them to have conscious understanding of the to-be-covered-materials, which may be done collaboratively, individually or online. Such atmospheres foster more active involvement and independence in learning since learners are more focused and responsible of their learning (O'Flaherty, \& Phillips, 2015). In other words, they are able to make connections between the learning they did before coming to class and class activities that reinforce their learning (Nielsen, 2012). Flipped instruction is defined as "....an act of delivering an outside-class direct instruction to the individuals in an attempt to have more strategic use of in-class time to further engage in group work, individualized and personalized attention" (Bergmann \& Sams, 2014, p. xi). Herman and Banister (2007) showed that direct instruction through lecture is inadequate when it comes to fostering more learners' involvement and their deeper thought (Bligh, 1998). The researchers argued that flipped instruction connects the use of online materials which then practiced through lecture to create active learning that puts the student at the center of learning and the educators become the guides (Burgan, 2006).

Although technology is a beneficial teaching tool, face-to-face instruction is still supported by researchers for information delivery. The challenging point is how face-to-face instruction could be incorporated into technology in order to enjoy the benefits of both a blended learning approach as an instructional technique in the most effective and efficient way (Neumeier, 2005). Although there is no consensus regarding the allocation of online and face-to-face instructional time (Garrison \& Vaughan, 2007), Garrison and Kanuka (2004) insisted on the maximum benefit when teachers arrive at the most desirable way to integrate_these two instructional components to meet the pedagogic needs of the target curriculum. This integration can eliminate problem of the shortage of time which prevents interactive activities. Traditional classrooms dominated by teachers' lectures cannot take account of learners' engagement (Berman, 2015). Moreover, grammar acquisition necessitates more effective methods to motivate learners in the in the grammar classroom. Teachers suffer from insufficient teacher-student and student-student interaction. Iranian EFL students appear to have difficulty learning a complete range of English materials presented by the teachers (Maleki \& Zangani, 2007) regardless of no or less communication in the classroom.

Although some researchers such as Bergmann and Sams (2009), Bishop and Verleger (2013), and Berrett (2012) confirmed the practicality of flipped classrooms, it can be argued that teacher' role in the flipped classroom has not sufficiently been recognized since they moves into the role of the coach or guide, who provide assistance for the learners how to integrate all that information, perform a skill, or interact with others face to face (Berman, 2015; Berrett, 2012), which is a source of concern for teachers. There also seems to be no clear-cut distinction of formal or communicative dimensions of flipped classrooms. This demands more research to uncover the hidden aspects of flipped instruction.

In a recent study, Ekmekci (2017) investigated the impact of flipped instruction on the development of writing skill among Turkish students. More specifically, he compared the effects of flipped and traditional face-toface writing classes on the basis of writing performances. The results of this experimental study showed that flipped writing classes improve students' writing proficiency more than the traditional lecture-based writing instruction.

Similarly, Hung (2015) explored the effects of flipping the classroom on English language learners' academic performance, participation levels, and learning attitudes. Investigating three different formats for flipped teaching, the researcher found that the structured and semi-structured flipped lessons lead to better learning outcomes, foster better learners' attitudes, and result in more effort to the learning process. Moreover, BauerRamazani, Graney, Marshall \& Sabieh (2016) attempted to define and describe the flipped learning and 
examined the possibilities to promote language acquisition in the context of Teachers of English to Speakers of Other Languages (TESOL). They also reported the possible benefits and challenges of the new method.

Last but not least, the flipped classroom requires the occurrence of learners' autonomy at home using online videos and actively taking part in class for effective discussions. In contrast with second language learners who rely on their own independent learning, foreign language learners might be greatly dependent on teachers' role in doing the tasks. This criterion seems to see foreign language students become pre-accustomed to laid-back learning, which relies on teachers' support rather than being individually involved in the problemsolving tasks (Wang, 2006), which recognized the practical role of flipped teaching and learning (Chambers, 2010; Kong, 2015). This also lies in sociocultural theory (Vygotsky, 1978) which shows that learners are able to self-regulate their learning experiences through meaningful interaction and mediation as well as scaffolded feedback directed toward the learners' zone of proximal development (ZPD) (Lantolf \& Throne, 2006). In other words, flipped classroom can be justified and well-supported by sociocultural theory since it suggests facilitating learners' engagement in the classroom that is caused by the instruction they received.

Using instructional materials as an online activity can bring about multiple situations in which development of a grammatical structure may be required. Merely learning the grammatical rules explicitly by formal representation cannot help use grammar effectively (Bergmann \& Sams, 2012). As a result, grammar teaching should involve an online activity, which results in the existence of multiple situations bringing about further elucidation of a grammatical structure, an example of which can be conditional sentences. Therefore, inspired by the sociocultural theory, the present study aimed to look into the effect of flipped teaching on the Iranian EFL learners' learning and retention of conditional sentences by addressing the following research questions:

RQ1. Does using flipped instruction have any statistically significant effect on Iranian intermediate EFL learners' learning of English conditional sentences?

RQ2. Does using flipped instruction have any statistically significant effect on Iranian EFL intermediate learners' retention of English conditional sentences?

RQ3. Are there any significant differences between flipped-taught classroom and traditional-taught classroom in terms of their effects on Iranian intermediate EFL learners' learning of English conditional sentences?

RQ4. Are there any significant differences between flipped-taught classroom and traditional-taught classroom in terms of their effects on Iranian intermediate EFL learners' retention of English conditional sentences?

\section{LITERATURE REVIEW}

Recent research has sufficiently demonstrated the effectiveness of flipped instruction on the learners' academic gains. Prunuske, Batzli, Howell, and Miller (2012) pointed out that the development of the learners' pre-existing knowledge by online lectures could result in their increased performance on lowerorder cognitive learning objectives. Meanwhile, in the classroom they can improve higher-order cognitive capabilities. Furthermore, benefiting from current computer software or mobile apps outside the classroom and exposing the learners to communicative environment inside the classroom enable learners to construct their knowledge through engaged learning activities.

In a quantitative study done by Strayer (2012), exposure to flipped and traditional instruction was examined regarding the learners' language learning achievement. The learners' perceptions about the learning environment were explored as well. The educational benefits of flipped teaching were recognized in the study since significant difference was observed between the flipped and traditional groups. In fact, the learners in the experimental group were reported to be in favor of cooperation in the learning environment fulfilled by flipped instruction in comparison with the control group undergoing the traditional instruction. The study aimed to broaden the scholars' insights regarding the practical use of this technique in paving the way for teachers and learners to perform as productively as possible. Moreover, flipped learning, according to the learners' perceptions, can be more in alignment with the learners' needs of 21 st century. 
Sahin, Cavlazoglu, and Zeytuncu (2015) took account of college students' achievements in their language courses when they were provided with videos in doing the related tasks of reading comprehension. The researchers encouraged the students to watch videos while reading in order to stimulate their comprehension. They were cordially invited to share their thoughts and have discussion with their peers regarding the videos in order to help them widen their viewpoints concerning the focused reading topic. In addition, the learners' level of self-efficacy increased by fostering their communicative skills, which was in converse with lowleveled self-efficacy learners who underwent traditional learning.

In his longitudinal research, Pence (2016) did a pilot study of a flipped learning with the participation of 70 students. In order to adhere to flipped learning environment, the students were accessed by prerecorded audio podcasts. While the students were in class, they were encouraged to have active learning by discussion on the audio files and directing their attention toward Power Points embedded with animation and diagrams, You Tube videos, and use of cell phones and iPads to conduct online searches related to in-class learning activities. Over the 2-year pilot study, the great level of satisfaction was reported by the students who were armed with the flipped classroom model.

In addition to above-mentioned studies confirming the effectiveness of flipped instruction, it should be theoretically taken into consideration. Flipped Learning intended to render a student-centered classroom through the use of technology causes more opened in-class time for interactive peer activities (Bishop \& Verleger, 2013, Gough et al., 2016, Krumsvik \& Jones, 2016). Students watching their teacher's instructional videos come prepared to their class and engage in classroom activities. The teacher spearheading collaborative and interactive activities attempts to heighten the relevant subject matter and develop more active students in class (Bergmann \& Sams, 2012, Gough et al., 2016). Since flipped learning is placed on the basis of interaction with others and interaction with digital tools, this study utilizes a sociocultural approach to learning as its theoretical basis. One of the primary concepts of sociocultural theory is its claim that the human mind is mediated (Lantolf, 2000). Lantolf believed that Vygotsky (1978) recognized a significant role for what he called 'tools' in humans' understanding of the world and of themselves. Lantolf claimed that Vygotsky advocated that humans do not act directly on the physical world without the intermediary of tools. In Vygotsky's opinion, symbolic tools or signs are artifacts created by humans under specific cultural (culture specific) and historical conditions, and by their very nature they carry with them the characteristics of the culture in question. They are applied as aids in solving problems that cannot be solved in the same way in their absence. In turn, they also have an influence on the individuals who use them in that they bring about previously unknown activities and previously unknown ways of conceptualizing phenomena in the world. Therefore, they are modified as they are passed from one generation to the next, and each generation reworks them in order to meet the needs and aspirations of its individuals and communities.

An important concept in sociocultural theory is known as the ZPD. According to Vygotsky, the zone of proximal development "is the distance between the actual development level as determined by independent problem solving and the level of potential development as determined through problem-solving under adult guidance or in collaboration with more capable peers" (Vygotsky, 1978, p. 86). It includes all of the knowledge and skills that a person cannot understand or perform on their own yet but is capable of learning with sufficient support and guidance. As people are allowed to develop their skills and knowledge, often by observing someone who is more capable than they are, they are able to progressively extend this zone of proximal development. In fact, as Vygotsky (1978) argued, the idea is to move learners from otherregulation (receiving learning support from a more knowledgeable person) to self-regulation (the learners' ability to do the tasks on their own) which shows the effectiveness of target instruction and the learners' development in the learning process. In a flipped classroom the teacher or more competent peers are present to provide learning support or scaffolding for performing instructional activities.

Scaffolding as a conceptual tool associated with ZPD accounts for the way that teachers help their students complete instructional tasks activities and entails evaluation, feedback, and tapering off support (Wood et al., 1976). Scaffolding involves a teacher's presence to constantly assess how a student gets along in performing a given task to make sure that the students do not get disoriented and their motivation for completing the task does not wane. To this end, the teacher should simplify the task by lessening the task requirements that the learner needs for completing the task (Wood, Bruner, \& Ross, 1976). Teachers can customize their feedback they give to spur learners' continual development, then taper off their support on 
the particular learning task in order to empower learners to move on to a level at which they perform the tasks unaided. In the Flipped Classroom, video lectures are viewed as a scaffolding. Since videos should be short and concise, teachers providing the video lectures can condense the instructional content in order to lower the degrees of freedom and requirements of a given subject (Bergmann \& Sams, 2014, Murray, et al., 2015). A flipped classroom frees up in-class time to set the ground work for more individual and small group instruction (Yarbro, et al., 2014). This offers the teacher the opportunity to be present in class to help students complete the task by keeping learners' interests unabated and the direction of the task clear, the key objective and focus of scaffolding (Wood, et al., 1976, Pea 2004). The technology in Flipped Learning is leveraged for scaffolding learners.

Recent studies above as well as inspired from sociocultural theory of learning show the significant role of flipped instruction in facilitating the learners' language achievement in different contexts. Thus, flipped teaching and its conscious utilization in the context of foreign language are demanding in order to see how it might affect the learners' development and retention of conditional sentences, which might produce insightful research areas in flipped teaching and learning.

\section{METHOD}

\section{Participants}

The participants of the study were selected using convenience sampling procedure. To add more value on the adoption of convenience sampling, Mackay and Gass (2005) also believe that researcher can rely on such sampling to appropriately initiate data collection procedures. Moreover, it also assists researchers to save the time, which is another point of dispute for the researchers regarding the selection of the related participants.

The present study was conducted with the participation of 60 students who were studying English in a private language institute named Donyaye Kia Language Institute, in Isfahan to investigate the effect of flipped instruction on their grammar learning. It is noteworthy that the participants were randomly divided into one experimental group $(n=30)$ and one control group $(n=30)$. The participants' age range was between 15 to 25 years old. To make sure about the homogeneity of the participants, they took Oxford Quick Placement Test (OQPT) to select intermediate language learners for the sake of data collection.

\section{Instruments}

The following instruments were used in the present study:

\section{Oxford Quick Placement Test (OQPT)}

Oxford Quick Placement Test (OQPT) was administered at the beginning of the study to select a homogenous sample in terms of language proficiency. It is noteworthy that the participants of the study were of intermediate level based on the OQPT scoring criteria. As to the purpose of the present study, QOPT includes 60 multiple choice items on vocabulary (30 items) and grammar (30 items). The rationale behind the application of the OQPT was firstly the fact that - compared to the other tests - the participants of the study were believed to be more familiar with the structure of this test. Secondly, this test, as previously mentioned above, can assist the researcher to go for homogenous participants of the study (Allen, 1992).

\section{Researcher-made Grammar Diagnostic Test (Pre-Test)}

The validity and reliability The English grammar diagnostic test, which was used as the pre-test of the study, was utilized to test the participants' initial knowledge of conditional sentences. The pre-test consisted of 25 multiple choice questions of conditional sentences from 'Grammar in Use' (2009) book (intermediate level). There was one score for every correct response.

Concerning the reliability measure of the pre-test, a pilot study was conducted with the participation of 20 intermediate learners (from another private institute with similar characteristics of the participants of the 
present study) to go for the test score consistency. Reliability coefficient was found to be 0.74 (using KR-21 formula), which seemed to be an acceptable value in terms of consistency of scores as highlighted in Farhady, Jafarpour, and Birjandi (1994). The reliability of the pre-test is shown in Table1.

Table 1. Reliability of Researcher-Made Grammar Diagnostic Test

\begin{tabular}{|c|c|c|c|c|}
\hline $\mathrm{N}$ & Mean & SD & Variance & Reliability \\
\hline 20 & 21.54 & 5.66 & 44.15 & 0.74 \\
\hline
\end{tabular}

\section{Researcher-made Grammar Achievement Test (Post-Test)}

The validity and reliability In order to investigate the effect of flipped instruction on the learners' development of conditional, the post-test was administered to take the learners' post scores into account and have their achievement investigated after the intervention. The same as the pre-test, it consisted of 25 multiple choice items chosen from 'Grammar in Use' (2009) book of intermediate version and concentrating on the target form, i.e. conditional sentences.

Regarding the reliability coefficient of the post-test, the same participants, who took part in the pilot study for the pre-test, received the post-test to check the consistency of the post-test scores with the application of KR-21 formula. The reliability was measured as 0.76 highlighting a logical amount of consistency measure. Reliability of the post-test is shown in Table 2.

Table 2. Reliability of Researcher-Made Grammar Achievement Test

\begin{tabular}{llllc}
\hline $\mathrm{N}$ & Mean & SD & Variance & Reliability \\
20 & 23.12 & 6.83 & 47.82 & 0.76 \\
\hline
\end{tabular}

As to the construct validation of the pre- and post-tests, the researcher checked the test items and finalized them with the consultation of the two Ph.D. holders of TEFL and one expert statistician to meet the validity issue of the test. The face validity of the test was also done by consulting the so-called experts.

\section{Delayed Post-Test}

Two weeks after the flipped instruction as the treatment of the study, the delayed post-test of grammar was administered to check the learners' retention on grammar learning. The delayed post-test questions were similar to those of the post-test; however, the items were reshuffled in order to reduce the potential practice effects.

\section{Data Collection Procedures}

Initially, the QOPT was administered among the experimental group as well as the participants in the control group to check their homogeneity in terms of their proficiency level and select intermediate learners at Donyaye Kia Language Institute in Isfahan, Iran according to convenience sampling. Prior to the administration of the pre- and post-tests of grammar, a pilot study was conducted to measure the reliability of the grammar pre- and post-tests. After that, the grammar pre-test was administered to diagnose the learners' initial knowledge of conditional sentences. Then, the experimental group received 12 one and a half-hour treatment sessions (both online and face to face) of flipped grammar instruction by WhatsApp, directing the learners' attention to the grammar tasks provided by the teacher. The explanations of the treatment sessions in WhatsApp and inside the classroom are provided in detail as follows. 
In WhatsApp environment, the learners were given a complete explanation regarding the purpose of the research in the first session and they were told that they had to stay online at certain times. The teacher invited the participants to hold the online sessions by creating a group and added the selected participants. In order to stimulate the learners' participation, the teacher informed them that they could get bonus to do their best in the WhatsApp group. In fact, WhatsApp was used as a mediator for introducing and providing the related tasks of conditional sentences. The learners were provided with grammar activities to provide a rather direct instruction of target conditional forms through the related audio and video files uploaded for further discussion inside the classroom. The teacher ensured that all the participants were able to parse the tasks and carry them out and expected them to ask for any ambiguities they might feel. WhatsApp probably aimed at providing formal instruction of grammar by presenting various instances of conditional forms to the learners. The teacher provided textual feedback for the learners' questions regarding the tasks. However, the teacher attempted to clarify the conditional sentences by stating the governing rules under conditional statements and encourage the learners to produce their own examples. In this way, input was given directly to the participants regardless of having discussion or interaction on the grammar tasks and challenging the learners, which were fulfilled inside the classroom. It is notable that the grammar tasks were also taken from the learners' workbooks and other supplementary material covered in their syllabus. After each online session, the face to face session of that online class was subsequently provided in the classroom environment to discuss the uploaded material focusing on conditional sentences.

Within the classroom, the teacher started the instruction by making a warm-up and directed the learners' attention to the tasks provided on WhatsApp to initiate the interactional grammar instruction. The learners were expected to have oral interaction with their classmates by sharing their opinions. Warm-up aimed at enhancing the learners' attention to interactively focus on the target forms. The grammar tasks, which were in printed formats as well, also included some instances of conditional sentences that were highlighted, bold, italicized, and underlined, aiming to indirectly activate the learners' noticing of target grammar . In fact, the grammar tasks were those uploaded in WhatsApp. The teacher gave the learners some time to work on the tasks on their own and then share their general understanding of the topic. The teacher attempted to guide the learners to focus on the target tasks by asking a lot of information and clarification questions and involving the majority of participants in the context of the classroom to discuss the matter and simultaneously producing the target conditional sentences regardless of explicitly explaining the rule underlying them. The teacher gave oral corrective feedback on the learners' answers for the purpose of better learning of the conditional sentences.

The learners were also encouraged to have peer interaction while working on the selected tasks of grammar. In fact, by meaningful interaction of participants created by teachers' questioning, the learners' attention was directed to the target grammar forms, which facilitated the production process. In fact, the purpose was to provide an opportunity for the learners to orally interact with their classmates and the teacher, while inspired from the previously-prepared material on the online environment, for the purpose of better and quality grammar learning, as well.

However, no mixture of technology enhanced instruction and face to face learning environments were applied in the control group and they underwent traditional instruction of grammar without benefiting from mobile apps and interactive classroom. In other words, the teacher tried to use whiteboard and initially provide the rules for making conditional sentences proceeded by some examples of them and asked learners to produce their own statements. No attempt was made to challenge the learners' wrong answers and they were merely given positive or negative feedback on their responses.

After 12 sessions of flipped grammar instruction by WhatsApp and classroom learning environment, the participants took the grammar post-test. Two weeks after the administration of the post-test, learners took a delayed-post-test to look into the two groups' retention of grammar learning. 


\section{FINDINGS}

\section{The First Research Question}

The first research question of the study aimed at investigating the learners' scores on the pre- and post-test affected by flipped instruction. Test of normal distribution (see Table 3) was initially carried out to see if the scores of the learners in both groups, i.e. experimental and control learners were distributed normally.

Table 3. Shapiro-Wilk Tests of Normality

\begin{tabular}{ccccc}
\hline & & \multicolumn{3}{c}{ Shapiro-Wilk } \\
\cline { 3 - 5 } & Group EC & Statistic & $\mathrm{df}$ & Sig. \\
\hline \multirow{2}{*}{ Pretest } & Experimental & .956 & 30 & .554 \\
& Control & .925 & 30 & .127 \\
& Experimental & .932 & 30 & .082 \\
Delayed Posttest & Control & .977 & 30 & .610 \\
& Experimental & .942 & 30 & .116 \\
\hline
\end{tabular}

First of all, tests of normal distribution were run to see if the data were distributed normally. The nonsignificant sig. values (>.05) of Table 3, the Shapiro-Wilk Table, indicate that the pattern of distribution of the scores was normal for the pre-test, post-test, and delayed post-test of both the experimental and control groups. Therefore, parametric tests could be used to analyze the data. Descriptive statistics for the experimental group are shown in Table 4.

Table 4. Descriptive Statistics for the Pre- and Post-Test of the Experimental Group

\begin{tabular}{ccccc}
\hline & Mean & N & Std. Deviation & Std. Error Mean \\
\hline Pretest & 14.8000 & 30 & 2.69801 & .54160 \\
Posttest & 19.6800 & 30 & 3.38100 & .68000 \\
\hline
\end{tabular}

The descriptive statistics in Table 4 demonstrates that the EFL learners learning of conditional sentences improved from the pre-test $(M=14.80)$ to the post-test $(M=19.68)$. Therefore, the flipped instruction descriptively resulted in improvement in the learners' grammar learning. To inferentially compare the mean scores of the experimental groups in the pre- and post-test, a paired samples t-test was run the results of which are provided in Table 5.

Table 5. Paired Samples T-Test Statistics for the Pre- and Post-Test of the Experimental Group

\begin{tabular}{|c|c|c|c|c|c|c|c|c|}
\hline & \multicolumn{5}{|c|}{ Paired Differences } & \multirow[b]{3}{*}{$\mathrm{t}$} & \multirow[b]{3}{*}{ df } & \multirow{3}{*}{$\begin{array}{c}\text { Sig. } \\
\text { (2-tailed) }\end{array}$} \\
\hline & \multirow[b]{2}{*}{ Mean } & \multirow{2}{*}{$\begin{array}{c}\text { Std. } \\
\text { Deviation }\end{array}$} & \multirow{2}{*}{$\begin{array}{l}\text { Std. Error } \\
\text { Mean }\end{array}$} & \multicolumn{2}{|c|}{$\begin{array}{l}95 \% \text { Confidence Interval } \\
\text { of the Difference }\end{array}$} & & & \\
\hline & & & & Lower & Upper & & & \\
\hline Pretest - Posttest & -4.88000 & 3.18553 & .62631 & -6.05406 & -3.59594 & -7.995 & 29 & .000 \\
\hline
\end{tabular}

Table 5 shows a significant improvement from the pre-test to the post-test $($ sig $(2$-tailed $)=.000, t=-7.99$, $\mathrm{df}=29$ ). The mean difference equals -4.88 and the $95 \%$ confidence interval $(\mathrm{CI})$ rests on -6.05 at the lower and -3.59 at the upper bound showing a large effect size (Cohen's $\mathrm{d}=-1.53$ ). Therefore, the Table indicates that the flipped instruction resulted in significant improvement in the Iranian EFL learners' learning of conditional sentences. 


\section{The Second Research Question}

The second research question of the study examined the learners' retention of conditional sentences when they were exposed to flipped grammar instruction. In doing so, the learners' responses to the grammar pre-test and delayed post-test are analyzed. Table 6 shows the descriptive statistics for experimental groups' performance on the two occasions.

Table 6. Descriptive Statistics for the Pre-Test and Delayed Post-Test of the Experimental Group

\begin{tabular}{ccccc}
\hline & Mean & N & Std. Deviation & Std. Error Mean \\
\hline Pretest & 14.8000 & 30 & 2.69801 & .54160 \\
Delayed Posttest & 20.2000 & 30 & 3.35505 & .60041 \\
\hline
\end{tabular}

The descriptive statistics in Table 6 demonstrates that learners' grammar learning improved from the pre-test $(M=14.80)$ to the delayed post-test $(M=20.20)$. The descriptive statistics also reported that the learners' mean score is higher on the delayed post-test $(M=20.20$, $)$ than on the post-test $(M=19.68)$ (see Table 4). Therefore, using flipped teaching provided an atmosphere for the learners to improve their retention of conditional sentences. To inferentially compare the mean scores of the experimental groups, Table 7 is provided in the following.

Table 7. Paired-Samples T-Test Statistics for the Pre-Test and Delayed Post-Test of the Experimental Group

\begin{tabular}{|c|c|c|c|c|c|c|c|c|}
\hline & \multicolumn{5}{|c|}{ Paired Differences } & \multirow{3}{*}{$\mathrm{t}$} & \multirow{3}{*}{$d f$} & \multirow{3}{*}{$\begin{array}{c}\text { Sig. } \\
\text { (2-tailed) }\end{array}$} \\
\hline & \multirow[t]{2}{*}{ Mean } & \multirow[t]{2}{*}{$\begin{array}{c}\text { Std. } \\
\text { Deviation }\end{array}$} & \multirow[t]{2}{*}{$\begin{array}{l}\text { Std. } \\
\text { Error } \\
\text { Mean }\end{array}$} & \multicolumn{2}{|c|}{$\begin{array}{l}\text { 95\% Confidence } \\
\text { Interval of the } \\
\text { Difference }\end{array}$} & & & \\
\hline & & & & Lower & Upper & & & \\
\hline $\begin{array}{c}\text { Pretest - } \\
\text { Delayed Posttest }\end{array}$ & -5.40000 & 3.49188 & .71438 & -6.33963 & -3.95011 & -7.708 & 29 & .000 \\
\hline $\begin{array}{c}\text { Posttest - Delayed } \\
\text { Posttest }\end{array}$ & -.52000 & 1.35684 & .23937 & -1.10722 & .07741 & -1.807 & 29 & .085 \\
\hline
\end{tabular}

Table 7 shows a significant improvement from the pre-test to the delayed post-test $($ sig $(2$-tailed $)=.000, t=$ $-7.70, \mathrm{df}=29$ ). The mean difference equals -5.40 and the $95 \% \mathrm{CI}$ rests on -6.33 at the lower and -3.95 at the upper bound showing a large effect size (Cohen's $\mathrm{d}=-1.54)$. The statistics, however, showed a non-significant improvement from the post-test to the delayed post-test $(\operatorname{sig}(2$-tailed $)=.085, \mathrm{t}=-1.80, \mathrm{df}=29)$. The mean difference equals -.52 and the $95 \%$ CI rests on -1.10 at the lower and .07 at the upper bound showing a negligible effect size (Cohen's $\mathrm{d}=-.38$ ). Therefore, it can be concluded that the flipped instruction resulted in significant improvement on Iranian EFL intermediate learners' retention of English conditional sentences.

\section{The Third Research Question}

The third research question of the study looked into the learners' grammar learning concerning the experimental and control groups' performance on the pre- and post-test of grammar after being exposed to flipped and traditional grammar instruction. Therefore, descriptive statistics are initially presented (see Table 8). 
Table 8. Descriptive Statistics for the Experimental and the Control Groups' Pre- and Post-Test

\begin{tabular}{cccccc}
\hline & Group EC & $\mathrm{N}$ & Mean & Std. Deviation & Std. Error Mean \\
\hline Pretest & Experimental & 30 & 14.8000 & 2.69801 & .54160 \\
& Control & 30 & 14.7200 & 2.59189 & .51360 \\
\multirow{2}{*}{ Posttest } & Experimental & 30 & 19.6800 & 3.38100 & .68000 \\
& Control & 30 & 14.8000 & 2.77312 & .55962 \\
\hline
\end{tabular}

The descriptive statistics in Table 8 highlight the fact that the learners' grammar learning in the experimental group $(M=14.80)$ was just a little higher than the mean score of the control group $(M=14.72)$, which showed that the there was a similarity of the pre-test scores in their grammar learning before the treatment sessions It, however, demonstrated that the mean score of learners' grammar learning in the experimental group $(M=19.68)$ was higher on the post-test than the mean score of the control group $(M=14.80, S D=$ 2.84), which also delineated that the experimental group, who benefited from flipped-taught classroom, had higher grammar learning than the control group on the post-test and the end of the research. Therefore, it seems that there exists a significant difference between the two groups' grammar learning. In order to compare the students' mean scores in the experimental and the control group, independent samples t-test for both the pre-test as well as the post-test of the two groups was run as in the following.

Table 9. Independent-Samples T-Test for the Pre-Test of the Experimental and Control Groups

\begin{tabular}{|c|c|c|c|c|c|c|c|c|c|}
\hline & \multicolumn{4}{|c|}{$\begin{array}{l}\text { Levene's Test } \\
\text { for Equality of } \\
\text { Variances }\end{array}$} & \multicolumn{3}{|c|}{ t-test for Equality of Means } & \multirow{2}{*}{\multicolumn{2}{|c|}{$\begin{array}{l}\text { 95\% Confidence } \\
\text { Interval of the } \\
\text { Difference }\end{array}$}} \\
\hline & \multirow[b]{2}{*}{$\mathrm{F}$} & \multirow[b]{2}{*}{ Sig. } & \multirow[b]{2}{*}{$\mathrm{t}$} & \multirow[b]{2}{*}{$\mathrm{df}$} & \multirow{2}{*}{$\begin{array}{c}\text { Sig. } \\
\text { (2-tailed) }\end{array}$} & \multirow{2}{*}{$\begin{array}{c}\text { Mean } \\
\text { Difference }\end{array}$} & \multirow{2}{*}{$\begin{array}{l}\text { Std. Error } \\
\text { Difference }\end{array}$} & & \\
\hline & & & & & & & & Lower & Upper \\
\hline $\begin{array}{l}\text { Equal variances } \\
\text { assumed }\end{array}$ & .178 & .675 & .107 & 58 & .905 & .08000 & .74500 & -1.39798 & 1.58998 \\
\hline $\begin{array}{l}\text { Equal variances } \\
\text { not assumed }\end{array}$ & & & .107 & 58 & .905 & .08000 & .74500 & -1.41810 & 1.57890 \\
\hline
\end{tabular}

The Levene's test in Table 9 shows a non-significant sig. value $(\mathrm{F}=.178$, sig. $=.675)$ indicating that the variances of the scores of the experimental and the control group were equal. Accordingly, the independentsamples t-test statistics showed a non-significant difference between the pre-test scores of the experimental and the control groups ( $\operatorname{sig}(2$-tailed $)=.905, \mathrm{t}=.10, \mathrm{df}=58)$. The mean difference equals .08 and the $95 \%$ CI rests on -1.39 at the lower and 1.58 at the upper bound, which highlight the similarity of the two groups' grammar learning before the treatment sessions of the flipped instruction.

Table 10 indicates the groups' performance on the grammar post-test. 
Table 10. Independent-Samples T-Test Statistics for the Post-Test of the Experimental and Control Groups

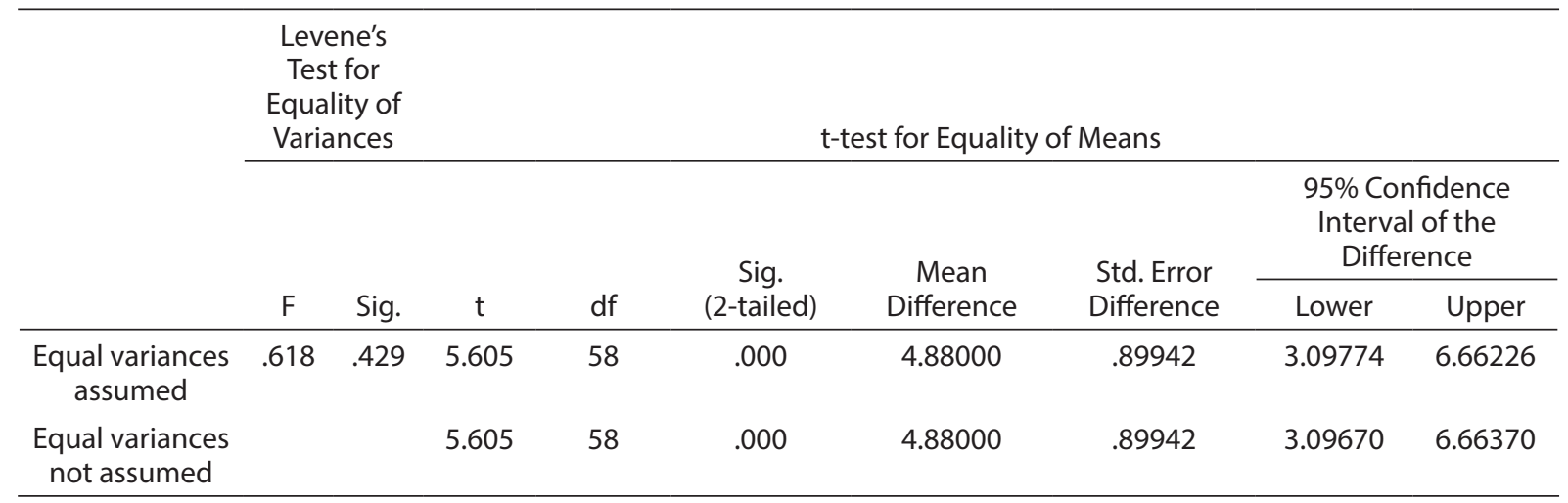

As Table 10 demonstrates, a non-significant sig. value $(\mathrm{F}=.618$, sig. $=.429)$ was observed, which showed that the variances of the scores of the experimental and control group were equal. Accordingly, the independentsamples t-test statistics showed a significant difference between the post-test scores of the experimental and the control groups (sig (2-tailed) $=.000, t=5.60, \mathrm{df}=58)$. The mean difference equals 4.88 and the $95 \% \mathrm{CI}$ rests on 3.09 at the lower and 6.66 at the upper bound, which showed a large difference and that the EFL learners in the experimental group outperformed the control group in grammar learning on the post-test. In other words, there was a statistically significant difference between the effect of flipped-taught classroom and traditional-taught classroom on Iranian intermediate EFL learners' learning of English conditional sentences. The results of the delayed post-test are also presented below.

\section{The Fourth Research Question}

The fourth research question of the study looked into the EFL learners' retention of conditional sentences by taking into account their grammar scores on the pre-test and the delayed post-test. First, descriptive data are provided in the following Table 11.

Table 11. Descriptive Statistics for the Experimental and the Control Groups' Pre-Test and Delayed Post-Test

\begin{tabular}{cccccc}
\hline & Group EC & N & Mean & Std. Deviation & Std. Error Mean \\
\hline Pretest & Experimental & 30 & 14.8000 & 2.69801 & .54160 \\
& Control & 30 & 14.7200 & 2.59189 & .51360 \\
Delayed Posttest & Experimental & 30 & 20.2000 & 3.35505 & .60041 \\
& Control & 30 & 14.9200 & 2.99112 & .54412 \\
\hline
\end{tabular}

The descriptive statistics in Table 11 shows the similarity of the learners' grammar score in the experimental group $(M=14.80)$ and the control group $(M=14.72)$ on the pre-test. However, as the Table reveals, mean score of the learners in the experimental group $(M=20.20)$ was higher on the delayed post-test than the mean score of the control group $(M=14.92)$, highlighting the outperformance of the flipped-taught classroom learners' grammar retention over the control group on the delayed post-test. In order to compare the students' mean scores in the experimental and the control group, independent samples t-test was used as in the following. 
Table 12. Independent-Samples T-Test Statistics for the Delayed Post-Test of the Experimental and Control Groups

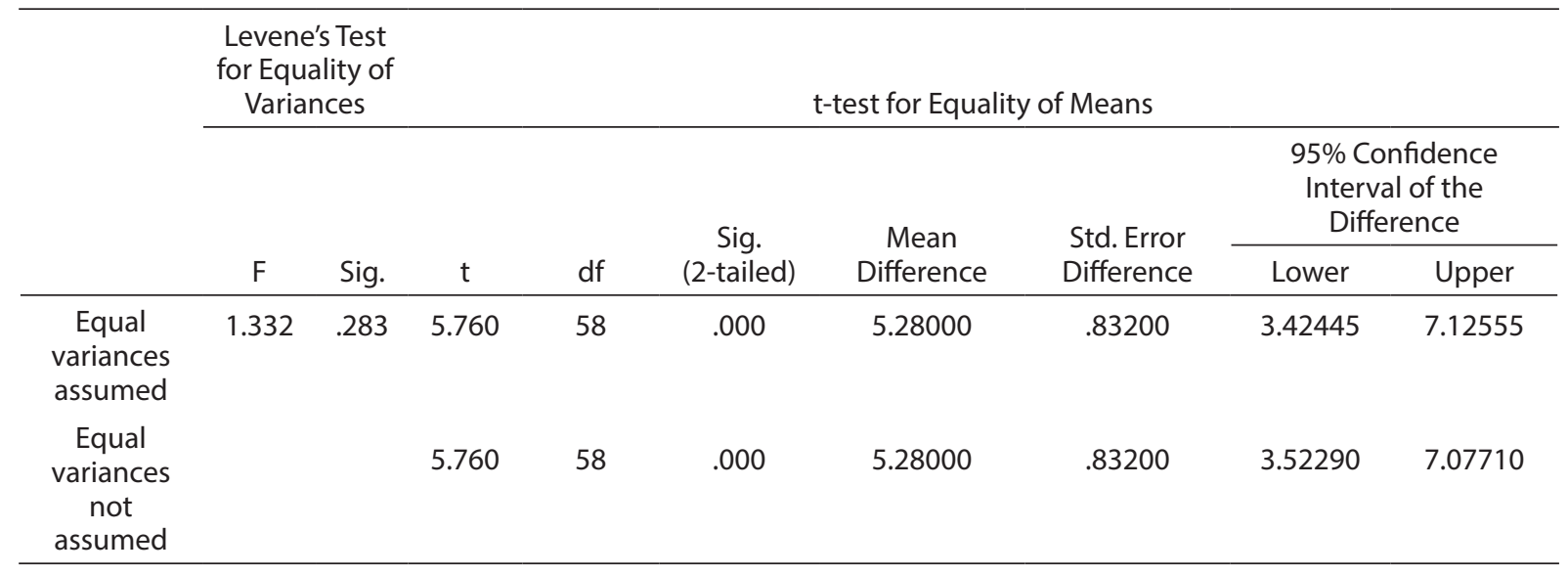

As with Table 12, a non-significant sig. value ( $\mathrm{F}=1.33$, sig. $=.283)$ was calculated, which denoted that the variances of the scores of the experimental and control group were equal. Accordingly, the independentsamples t-test statistics showed a significant difference between the delayed post-test scores of the experimental and the control groups ( $\operatorname{sig}(2$-tailed $)=.000, t=5.76, \mathrm{df}=58)$. The mean difference equals 5.28 and the 95\% CI rests on 3.42 at the lower and 7.12 at the upper bound, which reported a large difference and that EFL learners in the experimental group also outperformed the control group in grammar learning on the delayed post-test. In other words, there was a statistically significant difference between the effect of flipped-taught classroom and traditional-taught classroom on Iranian intermediate EFL learners' retention of English conditional sentences.

To sum up the results of the study, using flipped instruction had statistically significant effect on Iranian intermediate EFL learners' learning and retention of English conditional sentences.

\section{DISCUSSION}

This study attempted to examine the effect of flipped teaching and learning on the learners' improvement in learning and retention of conditional sentences. Thanks to controlling all variables such as age, preexisting knowledge and general achievement in English, the findings solely stemmed from the application of the Flipped classroom. As to the findings of the study, by measuring the pre-, post-, and delayed posttest scores of the learners in the experimental and control groups, it was found that the experimental group significantly outperformed the control group after the treatment (i.e. flipped instruction in teaching conditional sentences), demonstrating that integration of technology into the classroom was quite successful in helping the learners to improve their grammar learning (Ekmekci, 2017; Blake, 2008; Warschauer \& Healey, 1998). Hence, this study, to a large extent, proved that flipped teaching can be accounted for at the service of teaching grammar by involving the learners into the communicative context and putting them at the center their prior experiences. Moreover, the prevailing atmosphere in the flipped classroom positively impacted learners to display more interest, participation and engagement. The present study found empirical support to results obtained by Bergmann and Sams (2014) and Prunuske et al. (2012), who concluded that using technology and face-to-face instruction can pave the way for the learners to engage in an interactive learning environment and be as an active participant in the language learning process and improve their language skills and sub-skills. Watching videos containing specific content is seen as a source of preparation for in-class activities and discussions because students knew what points were going to be presented in class time. Moreover, concise format of videos enabled students to better retain the information presented in videos and to further feel secure for participating in class activities. The videos were viewed as a tool to for scaffolding the information as the reduction of task requirement and the degrees of freedom were intended to support the students in performing the in-class activities. 
From another point of view, flipped instruction could lead to improvement in the learners' grammar knowledge in comparison with the control group, which can be greatly dependent on the Iranian learners preference to use technology devices and discuss the tasks in the classroom. In fact, the learners' preference to use mobile apps (WhatsApp in this study) and its easy access to the educational materials provided by the teacher and discuss them in the face-to-face classroom instruction seemed to enhance the learners' enthusiasm to perform better than being exposed to traditional learning environment, which resulted in more improvement in grammar learning.

To add more value concerning the effectiveness of flipped teaching, Haung (2015), Berrett, (2012) and Sahin, et al. (2015) suggested that it can provide an atmosphere for teachers to monitor their teaching in the online learning environment (which could be the formal aspect of flipped teaching) while the feedback is given in the classroom to foster more interactive learning atmosphere in order for the teachers and learners to benefit from purposeful classroom involvement (which is probably the communicative aspect of flipped classroom). In fact, as argued by Strayer (2012) and Berman (2015), integration of online instruction into classroom activities can be positively applied in language teaching to direct the learners' attentions to the tasks and give feedback to the learners, assisting the learners to have better concentration on task by developing more interaction in the language classroom, which causes more chances of learners' participation in the learning environment resulting in their success in the learning process (Moranski \& Kim, 2016; Bishop \& Verleger, 2013).

Results were also indicator of the efficacy of flipped instruction on the learners' retention of grammar learning, which can be in alignment with Pence's (2016) research in which the learners who were armed with flipped instruction could maintain their language achievement during two years. It appears that flipped teaching helped learners of the current study to internalize the conditional sentences by encouraging frequent engagement in the classroom doing the selected tasks cooperatively (Prunuske et al., 2012) by benefiting from both teacher's support as well as peer feedback (Chambers, 2010). When it comes to the learners' retention of the conditional sentences, the teacher attempted to provide a mechanism through which the learners were exposed to conscious grammar learning environment by being able to do their own correction at the end of the treatment sessions, which makes the learning practice to be more consistent (Garrison \& Vaughan, 2007).

Finally, it is notable that findings of the present research showed that flipped teaching acted as the mediator between the learners and the teacher by providing a motivating learning environment for the learners. This lies in sociocultural theory of learning (Vygotsky, 1978) that is in favor of arming the learners with scaffolding to self-regulate their language learning process (Lantolf, 2000). Teacher's feedback in the flipped classroom can be found to be successful since it might target the learners' ZPD by helping them to be aware of their probable conversational errors and revise them accordingly through teacher's permanent support (Lantolf \& Throne, 2006). Flipped instruction could pave the way for EFL learners to manipulate the learning environment and foster more communication in the classroom (Vygotsky, 1978) to both develop and maintain their grammatical knowledge.

\section{CONCLUSION}

A conscious design of connecting video lectures and in-class tasks in flipped learning builds a bridge between home and school as two different social worlds. Flipped Learning enables learners to engage in a more interactive technology-infused and student-centered learning environment. In theory, Flipped Learning enables learners to build skills in collaboration, and using digital tools as resources, yet the research on flipped learning is in its infancy. Moreover, flipped classrooms can be especially promising in language learning contexts, given their potential to promote learner agency and consciousness raising. In fact, our results suggest that flipped instruction can promote classroom interactions that allow learners (a) to assume higher levels of autonomy in learning for longer periods of time and (b) to be more conscious of the grammatical structures taught via flipped clasrooms.

This study was conducted within the framework of sociocultural theory to justify the results of the present research. Quantitative measures of the pre- post- and delayed post-tests found that the students in the experimental group could significantly outperform the control group in their development of conditional 
sentences. However, the study also suffered some limitations. Firstly, convenience sampling was used to shoose the participants of the study because true randomization was not possible for the authors. Secondly, the long-term effect of instruction was tested after a two-week interval; future studies can focus on longer retention of learned EFL target forms. Thirdly, the level of English proficiency of the particiapnts of the study was limited to intermediate learners and the treatment only lasted for 12 sessions. Future studies can deal with learners of different levels of proficiency and integrate longer periods of treatment.

To sum up, the role of flipped teaching should be recognized as an appropriate methodology, which seems to be beneficial for both teachers and learners. The study can be of great significance regarding teaching grammar in educational settings such as language institutes. Teachers' awareness of flipped instruction teaching by applying computer software and mobile apps may help them teach grammar as effectively as possible, which demands teacher education to take productive measure in raising the teachers' awareness of flipped teaching. It is also recommended that qualitative research seems to be greatly missed in the literature to put much more value concerning the contributions of flipped teaching in English Language Teaching (ELT). Finally, teachers' and students' perceptions of flipped classroom should be positively directed toward its employment in different learning contexts for it makes the instruction more purposeful and successful.

\section{BIODATA and CONTACT ADDRESSES of AUTHORS}

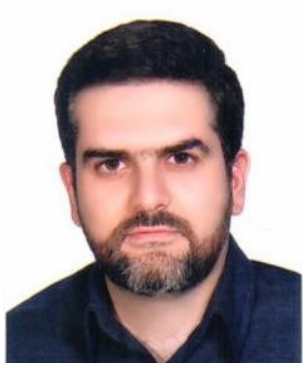

Ahmad NOROOZI is a PhD student of TEFL in the English Department, Isfahan (Khorasgan) Branch, Islamic Azad University, Isfahan, Iran. He received his B.A. in TEFL from ACECR Institute of Higher Education (Isfahan Branch), and earned his M.A. in TEFL from Isfahan (Khorasgan) Branch, Islamic Azad University, Iran. His main research areas of interest are Issues in Second Language Teaching Methodology, and Language Teaching and Technology. Ahmad Noroozi has been teaching EFL learners and TEFL student for the last 8 years. He has published some articles on language teaching methodology.

\section{Ahmad NOROOZI}

English Department

Address: Islamic Azad University, Isfahan (Khorasgan) Branch,

81595-158, Isfahan, Iran

Phone: +989132050799

E-mail: noroozi.a@entekhabgroup.com

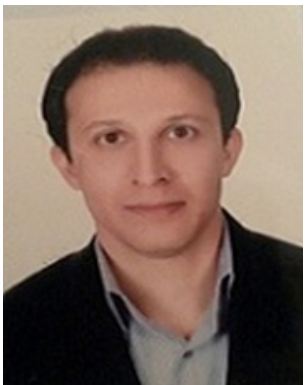

Dr. Ehsan REZVANI is an assistant professor of TEFL in the English Department, Isfahan (Khorasgan) Branch, Islamic Azad University, Isfahan, Iran. He received his B.A. in English Translation from Isfahan (Khorasgan) Branch, IAU (2006), and earned his M.A. (2008) and Ph.D. (2014) in TEFL from University of Isfahan. His main research areas of interest are Issues in Second Language Acquisition (SLA), Language Teaching Methodology, and Pragmatics. Ehsan Rezvani has been teaching EFL learners and TEFL student for the last 18 years. He has published several articles on language teaching and has presented papers in international conferences.

Ehsan REZVANI

English Department

Address: Islamic Azad University, Isfahan (Khorasgan) Branch,

81595-158, Isfahan, Iran

Phone: +989133191755

E-mail: rezvani_ehsan_1982@yahoo.com; e.rezvani@khuisf.ac.ir 


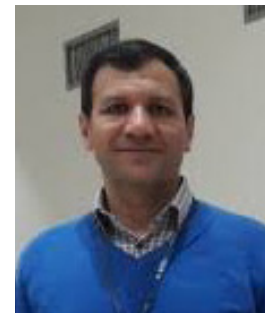

Dr. Ahmad AMERI-GOLESTAN is an assistant professor of TEFL in the English Department, Majlesi Branch, Islamic Azad University, Isfahan, Iran. He received his B.A. in English Translation from Isfahan (Khorasgan) Branch, IAU, and earned his M.A. and Ph.D. in TEFL from University of Isfahan. His main research areas of interest are Issues in Second Language Acquisition (SLA), and Language Teaching Methodology. Ahmad Ameri-Golestan has been teaching EFL learners and TEFL student for the last 25 years. He has published several articles on language teaching and has presented papers in international conferences.

Ahmad AMERI-GLOESTAN

English Department

Address: Islamic Azad University, Isfahan (Khorasgan) Branch,

81595-158, Isfahan, Iran

Phone: +989133007534

E-mail: a.ameri@iaumajlesi.ac.ir

\section{REFERENCES}

Allen, D. (1992). Oxford placement test 2 (New edition). Oxford University Press.

Bauer-Ramazani, C., Graney, J. M., Marshall, H. W., \& Sabieh, C. (2016). Flipped learning in TESOL: Definitions, approaches, and implementation. TESOL Journal, 7(2), 429-437.

Bergmann, J., \& Sams, A. (2009). Remixing chemistry class: Two colorado teachers make vodcasts of their lectures to free up class time for hands-on activities. Learning \& Leading with Technology, 36 (4), 22-27.

Bergmann, J., \& Sams, A. (2012). Flip Your Classroom: Talk to Every Student in Every Class Every Day. USA: International Society for Technology in Education.

Bergmann, J., Sams, A. (2012). Flip Your Classroom: Reach Every Student in Every Class Every Day. International Society for Technology in Education.

Bergmann, J., \& Sams, A. (2014). Flipped learning. London: Washington \& Eurospan.

Berman, R. (2015). His students were struggling, so he 'flipped' his classroom. XQ: The Super School Project. Retrieved online November 05, 2015, from http://www.upworthy.com/his-students-werestruggling-so-he-flipped-his-classroom

Berrett, D. (2012). How 'flipping' the classroom can improve the traditional lecture. Education Digest, 78(1), 36-41.

Blake, R. J. (2008). Brave new digital classroom: technology and foreign language learning. Washington, D.C: Georgetown University Press.

Bishop, J., Dr. Verleger, M. (2013). The Flipped Classroom: A Survey of the Research. American Society for Engineering Education. June 23-26, 2013.

Bligh, D. A. (1998). What's the Use of Lectures? London: Jossey-Bass.

Burgan, M. (2006). In defense of lecturing. Change: The Magazine of Higher Learning, 38(6), 30-34.

Chambers, A. (2010). Computer-assisted language learning: mapping the territory. Language Teaching, 43(1), 113-122.

Ekmekci, E. (2017). The flipped writing clkassroom in Turkish EFL context: A coamparative study on a new model. Turkish Online Journal of Distance Education, 18 (2), 151-167.

Farhady, H., Jafarpour, A., \& Birjandi, P. (1994). Testing language skills. Tehran: SAMT Publications.

Garrison, D. R., \& Kanuka, H. (2004). Blended learning: Uncovering its transformative potential in higher education. Internet \& Higher Education, 7(2), 95-105. 
Garrison, D. R., \& Vaughan, N. D. (2007). Blended learning in higher education: framework, principles, and guidelines. San Francisco, CA: Jossey-Bass.

Gough, E., DeJong, D., Grundmeyer, T., Baron, M., K-12 Teacher Perceptions Regarding the Flipped Classroom Model for Teaching and Learning. Journal of Educational Technology Systems 2017, Vol. 45(3), 390-423.

Hung, H. T. (2015) Flipping the classroom for English language learners to foster active learning. Computer Assisted Language Learning, 28(1), 81-96.

Herman, T., \& Banister, S. (2007). Face-to-face versus online coursework: A comparison of costs and learning outcomes. Contemporary Issues in Technology Education, 7(4), 318-326.

Kalin, J. (2012). Doing what comes naturally? Student perceptions and use of collaborative technologies. International Journal for the Scholarship of Teaching \& Learning, 6(1), 11-27.

Kong, S. C. (2015). An experience of a three-year study on the development of critical thinking skills in flipped secondary classrooms with pedagogical and technological support. Computers \& Education, 89, 16-31.

Krumsvik, R.J., \& Jones, L. Ø., (2016). Flipped classroom i naturfag: Finnes det en sammenheng mellom omvendt undervisning (flipped classroom) og elevprestasjoner i naturfag? Norsk Pedagogisk Tidsskrift. 1-2016, p. 61-73.

Lantolf, J. P. (2000). Sociocultural theory and second language learning. Oxford: Oxford University Press.

Lantolf, J. P. (2004). Sociocultural theory and second and foreign language learning: An overview of sociocultural theory. In K. van Esch, and O. St. John (Eds.), New insights into foreign language learning and teaching. Frankfurt am Main: Peter Lang.

Lantolf, J. P., \& Thorne, S. L. (2006). Sociocultural theory and the genesis of second language development. Oxford: Oxford University Press.

Maleki, A., \& Zangani, E. (2007). A survey on the relationship between English language proficiency and the academic achievement of Iranian EFL students. Asian EFL Journal, 9(1), 86-96.

Moranski, K., \& Kim, F. (2016). 'Flipping' lessons in a multi-section Spanish course: Implications for assigning explicit grammar instruction outside of the classroom. Modern Language Journal, 100 (4), 1-23.

Murray, D., Kozniec, T., McGill, T., (2015). Student perceptions of Flipped Learning. School of Engineering and Information Technology. Australian Computer Society.

Neumeier, P. (2005). A closer look at blended learning - parameters for designing a blended learning environment for language teaching and learning. ReCALL, 17(2), 163-178.

Nielsen, L. (2012). Five reasons I'm not flipping over the flipped classroom. Technology \& Learning, 32(10), 46-46.

O'Flaherty, J., \& Phillips, C. (2015). The use of flipped classrooms in higher education: A scoping review. The Internet and Higher Education, 25, 85-95.

Pea, R. D. (2004). The Social and Technological Dimensions of Scaffolding and Related Theoretical Concepts for Learning, Education, and Human Activity. The Journal of the Learning Sciences, 13(3), 423-451.

Pence, P. L. (2016). Flipping a first-year medical-surgical associate degree registered nursing course: A 2-year pilot study. Teaching and Learning in Nursing, 11(2), 52-57.

Prunuske, A., Batzli, J., Howell, E., \& Miller, S. (2012). Using online lectures to make time for active learning. Genetics, 192(1), 67-72.

Sahin, A., Cavlazoglu, B., \& Zeytuncu, Y. E. (2015). Flipping a college calculus course: A case study. Journal of Educational Technology \& Society, 18(3), 142-152. 
Strayer, J. (2012). How learning in an inverted classroom influences cooperation, innovation and task orientation. Learning Environments Research, 15(2), 171-193.

Vygotsky, L. (1978). Mind in society: The development of higher psychological process. Cambridge: MA: Harvard University Press.

Wang, H. (2006). Teaching Asian students online: What matters and why? PAACE Journal of Lifelong Learning, 15, 69-84.

Warschauer, M., \& Healey, D. (1998). Computers and language learning: An overview. Language Teaching, $31,57-71$.

Wood, D., Bruner, J.S. \& Ross, G. (1976). The role of tutoring in problem solving. Journal of Child Psychology and Psychiatry, 17, 89-100

Yarbro, J., Arfstrom, K., McKnight, K., McKnight, P., (2014). Extension of a review of Flipped Learning. Creative Commons Attribution. Retrieved from the Flipped Learning Network website: http:// flippedlearning.org/cms/lib07/VA01923112/Centricity/ 